\title{
Rettelse til Grundtvig Studier 2000
}

Nogle rettelser fremsendt af Hans Kuhn til bidraget Grundtvig and the War that changed Danish Identity (Grundtvig Studier 2000, s. 190-202) blev desværre ikke inkorporeret i teksten, inden årgangen gik i trykken. Det drejer sig om følgende:

s. 193, linie 3 f.n.: udtrykket »on New Year's Day« udgår (Christian VIII døde 20. januar 1848).

s. 195, linie 3 f.o.: $\quad$ efter»...meanest animal« tilføjes: »Grundtvig may also have had in mind the dragon as the healdic symbol of the pagan Wends, once living in an area where in his day he saw indications of pagan thinking in German romantic philosophy."

s. 196, linie 2 f.o.: efter verscitatet på dansk tilføjes. »This may be a reference to the beginning of the Danish Rimkrønike.«

s. 197, linie 19.f.o.: »twist « > »fashion«.

s. 202, linie 14 f.o.: »krønike« > »feature article«. 